\title{
Islamic vigilantism and women in social media
}

\author{
Md. Sayeed Al Zaman \\ Department of Journalism and Media Studies, Jahangirnagar University, Savar, Dhaka, \\ Bangladesh \\ Email: ovi.sayeed@yahoo.com
}

\begin{abstract}
In Bangladesh, the number of cyber-citizens has been skyrocketing since the 2010s. Violence against women is also proliferating along with the presence of Islam in public spheres and discourses. Using thematic analysis, this study analyzes the discourse data collected from Facebook, the dominant social media of Bangladesh. The key aim of the research is to find out the bedrock of Islamic vigilantism and verbal aggressiveness against women in social media. Subsequently, three interlinked themes have been explored: women's religiosity, women's attire, and women's virtue. The findings have shown that men mainly capitalize on these three conventional and stereotyped ideas of popular Islam to conduct vigilantism against women in social media, which is most often accompanied by different types of verbal aggressiveness. Further, this study considering deep-rooted misogyny and patriarchy in Bangladesh society argues that these factors might have contributed to directing online vigilantism against women. As little research has been done in this area, this research study would lead to further researches in this area.
\end{abstract}

Keywords: Islam, vigilantism, women, social media, Bangladesh 


\section{INTRODUCTION}

Women in the South Asian region have a long history of exploitation and backwardness thanks to men's social authority and domination (Hashmi, 2000). All social systems, customers, and religions are man-made institutions that participate in this job. As a result, disparity along the gender line emerges with the further reinforcement of the disparity. In India, for example, more than half of its women are remained unemployed, and the bulk of men do not want women to work outside of the home ("Why India," 2018). Thus, social asymmetry begins through economic asymmetry. The scenario in Bangladesh is not so unlike. It is to note that, societies irrespective of religions deprive women of essential social rights. India and Bangladesh are Hindu and Muslimdominated societies, respectively, but the economic deprivation of women is identical. Therefore, it should not be concluded that Islam or Hinduism alone create a sphere of exploitation. Rather, it might be a structural exploitation based on a misogynistic social system.

In the 1990s, a wave of social networking took place around the world thanks to the internet. With this, the much-hyped Fourth Wave of Feminism born aiming at a promising cyberworld for women and reconstructing a global sisterhood (Plant, 2000; Wajcman, 2010). The growing popularity of social media in Bangladesh is a 2010s-phenomenon like the other South Asian countries, such as India and Pakistan. Of at least thirteen types of social media platforms (Aichner \& Jacob, 2015), Facebook has become the most used social media platform in Bangladesh, India, and Pakistan (Social Media, 2019). The limited participation of women in social media compared to men further illustrates the digital divide along the gender line both in India and Bangladesh (PTI, 2017). Therefore, men would dominate social media as well. But what is the nature and instruments of such domination? An influential action of domination used by men is vigilantism: violence against women (VAW) is one of its outcomes. In this context, if we consider Islamic vigilantism as an instrument of patriarchal domination, how should we draw a connection between Islamic vigilantism and women in social media? What is the main ground of Islamic vigilantism that men used to display destructive behavior against women in social media? This study attempts to explore this intersection and answer the relevant inquiries.

The following discussion is divided into four main sections. First, the relevant literature is studied and synthesized. It would provide a theoretical understanding of the previous studies related to the topic. Second, in the methodology section, the description of data collection and data analyses are 
presented. Third, the findings are discussed under three themes that are emerged from the dataset. Fourth, the key findings are summarized and discussed in light of previous literature. Further explanation of causality is also presented to some extent. Some limitations of this study are also mentioned in the end.

\section{LITERATURE REVIEW}

\section{Di/vigilantism}

The term vigilante means "watchman" or "guard" (Smallridge et al, 2016), Johnston (1996) defines vigilantism as "a social movement giving rise to premeditated acts of force-by autonomous citizens" (p. 232). He further postulates six features that vigilantism encompasses: planning; voluntary engagement of citizens; constitute a social movement; use or threaten to use of force; arise from fear of the collapse of the established order and aims to control social situations (Johnston, 1996; Smallridge et al., 2016). Further, vigilantism has three categories: crime control vigilantism, social group control vigilantism, and regime control vigilantism (Rosenbaum \& Sederberg, 1974). When vigilantism meets digital media, it creates a new phenomenon that we may call digilantism (Jane, 2016; Nhan et al., 2017; Prins, 2010; Schwarz \& Richey, 2019). It has more nicknames, such as cyber-vigilantism (Kosseff, 2016; Smallridge et al., 2016), digital vigilantism (Trottier, 2017), internet vigilantism (Chang \& Poon, 2017; Herold, 2008), and online vigilantism (Klang, 2015). Digilantism might disrupt Johnston's six features of vigilantism. For instance, digilantism not necessarily has to be premeditated and planned. The main reason could be the unique nature of online interaction and cyber-mob: digilantes might barely know each other while voluntarily participate in digilantism (Baldauf et al., 2017). As a result, digialtism coule be spontaneous that eliminates the possibility of planned vigilantism.

\section{Vigilantism as a shared ideology}

The transmission view of communication discusses the role of communication in transmitting information to others to control. Having said that, Carey (2008) considers communication as not merely a way of transporting information, rather a string to stick a group of individuals together and also, an instrument for the maintenance of society. He proposes his ritual view of communication to further delve into the significance of communication that represents a shared belief of a society in a given time. Further, communication 
makes social transformation possible (Carey, 2008; Foucault \& Melican, 2007). The ritual view of communication discusses the underlying feature of sociability: association, cohesion, sharing, and so on, those are inevitable elements to form a commune (Carey, 2008). On the other hand, communication in the social context carries the ideologies of individuals and groups. Put another way, communication not only produce meaning but also produce and reproduce the relation of domination (Brown, 1978; Holliday, 2010; Mumby, 1989). In that sense, (Islamic) vigilantism might be a shared ideology. It also might be stated that new-age communication technology and services including SNSs play an important role where spiritual beliefs and values and politics of ideologies are put into practice (Foucault \& Melican, 2007). Therefore, SNSs are promoting rituals or shared beliefs one step further. While patriarchy meets Islam, the synthesis of these two might promote Islamic vigilantism against women (Mannan, 2011). On one occasion, men may wish to control women through vigilantism while, on another occasion, women trying to avail more liberty may cross the male-made limits and violate men's expectations. In such a condition, destructive communication may take place in the form of verbal aggressiveness. Verbal aggressiveness as a destructive behavior can be available in social media as well, where contestation between men and women is reproduced.

\section{$\mathrm{Di} /$ vigilantism and destructive behavior}

Destructive aggressive communication has two interrelated forms: hostility and verbal aggressiveness (Littlejohn \& Foss, 2009). As an interpersonal communicative trait, hostility exhibits "irritability, negativity, resentment, and suspicion”. On the contrary, verbal aggressiveness as an informal communication/behavior identifies the tendency to attack the self-concept of others instead of their topic of communication (Infante \& Rancer, 1996; Infante \& Wigley, 1986; Littlejohn \& Foss, 2009). It may arise from the combination of high assertiveness and low responsiveness (Martin \& Anderson, 2007), and could be high and low based on the personality traits of the individuals (Infante et al., 1992). The diverse forms of verbal aggressiveness can be character attacks, competence attacks, ridicule, teasing, profanity, attacks on physical appearance, threats, malediction, background attack, and non-verbal behavior (Littlejohn $\&$ Foss, 2009). Although verbal aggressiveness has often been positioned into the interpersonal domain, it is quite common in group communication as well (Anderson \& Martin, 1999). Netizens frequently display verbal aggressiveness in SNSs (Bekiari \& Pachi, 2017) which subsequently leads to communication 
dissatisfaction (Anderson \& Rancer, 2007). Four probable reasons can be postulated those may cause verbal aggressiveness: psychopathology, disdain for other, social learning of aggression, and deficiency in argumentative skills (Littlejohn \& Foss, 2009). These causes produce some negative effects too, such as humiliation, feeling of inadequacy, embarrassment, depression, hopelessness, and despair (Infante, 1987). In many occasions, vigilantism coupled with religion produces explicit destructive behavior and danger.

\section{Religious vigilantism}

It is almost two decades since India, the largest democracy in the world, has been suffering from a new genre of nationwide crisis known as moral policing. It is a form of public vigilantism where the self-proclaimed protectors of Indian culture enforce a code of morality. Publics and cops both comprise such vigilante groups ("Cops didn't trip," 2005). These vigilante groups or moral polices humiliate and chase away lovebirds from parks ("Moral Police," 2010), storm tourists for their decadence that is "immoral" and goes against "Indian culture" ("India's moral police," 2006), abuse and make filthy comments (Banerjee, 2019), break into bars and attack pubs (Nanjappa, 2009), vandalize art exhibition (Nandi, 2013), and even condemn beauty parlor (Ahmad, 2005). Simply, they are against the penetration of "Western culture" that is allegedly corrupting the uniqueness of Indian culture, though there has been enough room for doubt against the belief of India's "exclusive culture" (Samant, 2009). Furthermore, sectarianists as moral police who formed the "Cow-protection Group" and conduct the "Cow-protection Movement" in India have already terrified the minorities. In the last three years, cow vigilantes hacked at least 44 people to death and left 280 injured in more than 100 attacks (Marlow, 2019). Religious moral policing is commonplace as well as a functioning phenomenon across the globe irrespective of religion. In many Islamic countries like Iran (Gasht-e Ershad supported by Basij Militia), Saudi Arabia (Committee for the Promotion of Virtue and the Prevention of Vice, or Mutawa), Malaysia (Federal Territories Islamic Religious Department) and Sudan (Public Order Police), morality policing is state-sponsored (Monitoring, 2016). In Israel, Mishmeret Tzniyut (Modesty Squad) as a Jewish vigilante group is active to punish "immorality" and "disobedience" (Topel, 2012). Religious fanaticism in Bangladesh had been different in nature and degree unlike many other relatively rigid Muslim societies like Wahabi-dominated Saudi Arabia and Shia-dominated Iran. 


\section{Contemporary Islamic Revivalism}

Despite the majority of Muslims had been religiously moderate in Bangladesh (Schendel, 2009; Uddin, 2006), political Islam has been gaining momentum since 1975 (Riaz, 2016, 2017). However, recent socioreligious and religiopolitical trends are forecasting all the possibilities of new Islamic revivalism in Bangladesh that may have already entered the public domain and discourses surpassing the private realm (Islam \& Islam, 2018). Based on this ground, it can be implied that the rising Islamism could create a supportive environment for germinating a new version of vigilantism. Besides, enforcement of sharia, improvised Islamic code of conduct, popular Islamic notions and practices might get privilege in Islamic vigilantism. In Bangladesh, alongside the intrusion of Islamism into the public sphere, a new online-based public sphere is also on the making. This digital public sphere (Mudhai et al., 2009; Schäfer, 2016)"number-of-pages":"269","source":"Google Books","event-place":"New York","abstract":"This book examines the claims that new information and communication technologies (ICTs, online public sphere (Al-Saggaf, 2006; Dahlberg, 2001; Poor, 2005), public sphere 2.0 (Ruiz et al., 2011), or internet public sphere (Papacharissi, 2002)2002 has been becoming heavily crowded by online publics (BTRC, 2019; Social Media Stats Bangladesh, 2019). Thereby, a significant shift in public discourse from off- to online has been coming about. These two contemporary but substantial phenomena: Islamic revivalism and the expanding digital public sphere, might intersect at some point. Along with this, online misogyny emerges as a form of digilantism against women.

\section{Women and misogyny}

In this part of the discussion, I would like to draw attention to the current situation of misogyny and women. It has often been promulgated that women in Bangladesh are being rapidly empowered in many ways (and it is partially fair), such as employment, social status, human rights, and so on (Chaity, 2017, 2018). However, gender-based violence (GBV) is still highly active in society. To some extent, for better conduction, GBV has been shifted into cyberspace having a new identity: gender-based online violence (GBOV) (Wilk, 2018), or simply, online misogyny (Ging \& Siapera, 2018; Jane, 2017a; Moloney \& Love, 2018). Expressions of online misogyny are manifold, but few dominate the others, namely: flaming, revenge porn, denigration, outing, etc. Jane (2014b, 2014a, 2017)the mainstream media has identified on-line vitriol as a worsening problem which is silencing women in public discourse, and is 
having a deleterious effect on the civility of the public cybersphere. This article examines the disconnect between representations of "e-bile" in media texts, and representations of e-bile in academic literature. An exhaustive review of thirty years of academic work on "flaming" shows that many theorists have routinely trivialized the experiences of flame targets, while downplaying, defending, and/ or celebrating the discourse circulated by flame producers. Much contemporary scholarship, meanwhile, ignores e-bile completely. My argument is that this constitutes a form of chauvinism (in that it disregards women's experiences in on-line environments, emphasizing flaming, uses "e-bile" to address these misogynistic expressions and perpetration against women in cyberspace. Further, she also examines the functionalities of the online mob that are comprised of vigilantes to shame and disparage women in SNSs (Jane, 2016, 2017b). Thus, a growing body of literature is indicating how online vigilantism like offline is orchestrating a new threat for women.

\section{Islam, vigilantism, women, and social media}

This part takes a closer look if there has any investigation been done so far to explain the correlations between Islamic vigilantism, women, and social media. Misogyny based on popular Islam (Gaffney, 1992) has been a known phenomenon in Bangladesh, although misogyny has been existing in this land long before Islam came (Hashmi, 2000). While misogyny is considered as the root of all plights of women (Manne, 2018; Srivastava et al., 2017), the rise of popular Islam in Bangladesh, as it seems, has been making the social life of women more challenging (Mannan, 2011). The prime reason could be: Islamic priests such as mullah and Maulvi, secondary literature like mythologies and hadith, are the main sources of popular Islam that are full of misogynistic remarks (Hashmi, 2000). Besides, pan-Islamism is seemingly getting stronger worldwide so do the rise of popular Islam in Islamic nations, which is allegedly curbing women's social rights to a certain degree (Esfandiari, 1997; Ozdalga, 2013; Ramazani, 1993; Schilder, 1990). Although Hasan (2012) wants to imply that Islam is falsely charged with misogyny by the Western feminist scholars, he fails to acknowledge the growing incidents of violence against women and girls (VAWG) in the name of Islam, especially in the Arab countries, although Islam promote moderate rights for women in social activities, clothing, discipline and religious performs, and moral virtues (Barlas, 2019; Douki et al., 2003; Saadawi, 2015). Based on the previous literature, this study attempts to answer the following research question. 
$R Q$ : What are the main pretexts for men to conduct Islamic vigilantism and verbal aggressiveness against women in social media?

\section{METHODS}

In the digital age, cyberspace is utilized as the free source of a huge amount of data for social researchers (Bordens \& Abbott, 2017). The present study is a qualitative analysis and the data for analysis are mainly discourse data produced on Facebook, the dominant social media of Bangladesh. This data has been extracted from the Facebook public page of BBC News Bangla by Netvizz. This automated data extraction application is widely used by social media analysts (Rieder, 2013). It is to mention that these randomly collected discourse data were generated during a social media campaign in the first week of April 2019, which is popularly known as "Ga gheshe daraben na" (Do not stand too close to my body). The online campaign was aimed to protest the rapidly increasing incidents of women's harassment in public transports of Bangladesh (BBC News, 2019; Momin, 2019). This particular online campaign has been selected intentionally considering its widespread and intense impact not only in cyberspace but also in real space. Moreover, no other feminist online movement in Bangladesh earned such huge public attention.

This study has used thematic analysis (TA) to analyze the discourse data. TA is often being ignored as a comprehensive research method (Boyatzis, 1998; Roulston, 2001) and frequently merged with content analysis (Vaismoradi et al., 2013). It was developed as a healthcare research method and now is being used in social sciences and humanities as well (Braun \& Clarke, 2006). TA is a six-phase approach that derives codes from an unstructured dataset to build meaningful categories (Braun, 2013; Braun \& Clarke, 2006; Terry et al., 2017). Categories and sub-categories turn into a few distinctive themes that contain the whole essence of the dataset. The six consecutive phases of TA are (a) familiarizing with data; (b) generating initial codes; (c) searching for themes; (d) reviewing themes; (e) defining and naming themes, and (f) and producing the report (Braun \& Clarke, 2006). Unlike grounded theory, TA in traditional qualitative research follows a deductive process in which the data are "segmented, categorized, summarized, and reconstructed in a way that captures the important concepts within the data set" (Ayres, 2008: 867).

The present dataset contains 1,474 comments of Facebook users. I have selected Facebook due to its unparalleled number of users compared to the other 
SNSs in Bangladesh (Social Media, 2019). The comments have been extracted from the official Facebook page of BBC Bangla, which has the highest reach as an online news portal in Bangladesh. Further, the BBC has a global reputation as a media organization as well. In the first stage, I read the conversations in the dataset carefully to generate codes. Thereafter, few categories were made based on the identified codes. In the next phase, I tried to generate a few preliminary themes so that the categories might fit into these themes. As TA is an iterative process, so I reviewed my dataset further to initiate more categories and/or themes. Lastly, after careful observation and identification, I found three major themes for the dataset that might be able to answer the research question of this study. To provide clearer and substantial answers to the research question, I added relevant and representative excerpts from the dataset.

\section{RESULTS AND DISCUSSION}

\section{Women's religiosity}

The dataset primarily signals the importance of religion and religiosity that subsequently dominates and dictates the discourse. I want to clarify at first what I mean here with religion/religiosity. First, religion or dharma is often been addressed in a sober sense which is more associated with morality and everyday lives of Bangladesh Muslims (Devine \& White, 2013). In this definition, religion or religiosity has little to do with theological Islam, rather it would merely denote conventional socio-cultural practices. Second, the notion of religion may also identify Islam as a political thing. However, both are in one way or another connected to popular Islam (Gaffney, 1992) and serves the interest of patriarchy (Mannan, 2011). I would like to borrow both interrelated ideas to apply in this section where necessary. Nevertheless, either notion ultimately produces conflict between the social interests of men and women.

It is noticeable that a lion's share of Muslim men as netizens tend to defend their religion which is Islam from perceived obscenity by engaging in discourse. They use a wide variety of terms: Muslim, Islami, dharma, iman, mumin, to refer to Islam. Saying these, they tend to portray their religiosity and concern for Islam as well. Both directly and indirectly, they try to impose their personal beliefs of Islam on others perhaps to enhance their "open self" (Frey, 2018). It is to note that not always their statements in the name of Islam are true, rather, as previously explicated, it is based on other secondary or tertiary sources except the Quran. This predisposition hints about the wide approval 
of popular Islam to men. Put another way, to most Muslim men, it looks like popular Islamic knowledge eclipses the true essence of Islam.

"Only Islam has given the proper and complete rights and security to women. If these women would obey the rules of Islam, they might not need to protest being naked."

"Wearing a t-shirt for women is haram in Islam."

"Islam has prohibited illegal relationships between men and women. According to sharia, Muslim women must maintain veil as a Faraz [...] Doing the opposite is haram, but when they obey the rules, they would get protected and safe from rape and eve-teasing."

Their anxiety to preserve Islamic virtues have also been seen. In this case, they try to set a moral boundary and/or impose their version of morality in the guise of Islamic proselytization. It is not necessary whether or not their declarations are truly mentioned in Islam or not: what matters is perhaps the show-off of their Islamic knowledge. This may be the formal version of moral policing: enforcing women to accept the proposed norms engendered by men.

"In a Muslim country like Bangladesh, (to women) is it acceptable to protest like this (wearing a t-shirt)? First, obey Islam, you will automatically be secured (from man)."

These bold statements suggest that men not only deliberately wield communicative power on women which is derived from typical patriarchic society but also promulgate Bangladesh society as a "Muslim" society that is secular by birth (Lewis, 2011; Riaz, 2016; Schendel, 2009). Such validations may curb the rights of religious minorities. Mostly, Hindus along with women tend to be admonished by the majority if anything goes wrong: in fact, these two are the easily available scapegoats.

In such circumstances, certifying Bangladesh as an "Islamic" country may serve two purposes concurrently: undermining the religious minorities of Bangladesh, and enchaining women with patriarchal (mis)interpretation of Islam. Hindus and Jews are the two foremost religious adversaries for the Muslims: the first one for geopolitical and regional reasons and the second one is Muslims' eternal rivalry from the early days of Islam. Therefore, if anything goes supposedly wrong, Muslims tend to admonish these two religious' communities.

"You live in the third biggest Muslim country, but (want to) lead your life like Jews-atheists, it would not be possible here. If you want to cease 
extramarital affair, sexual harassment, rape, and other crimes, then follow the Islamic rules for your family, society, and country."

"Malauns (Hindus) are such hypocrites that if they see anything negative related to Islam, they start disseminating it."

These dominant dialogues also clarify how men emphasize Islamic virtues while discussing women-related issues. Interestingly, the political-ideological conflict between Islam and the West has been embedded in the comments of the Muslim men. Western philosophies like feminism, Western culture like jeans and t-shirt, Western countries like the United States have been seriously degraded and vilified in the discourse.

"These (the campaigning) are the mechanism of feminist sluts. After getting fucked a hundred times, they pretend to be virgins while commuting in public transports."

"Wearing tight jeans and showing your ass, you are saying to respect women? Alas! You women live like Americans (that is obscene) and want justice like Saudi Arab (that is ideal)."

These expressions of religiosity, on the one hand, can be a makeshift attitude to properly exploit women in cyberspace too. On the other hand, men's aggressive and policing attitude might be originated from their ordinary knowledge of Islam. If the first one is true, then popular Islam in Bangladesh has been reinforcing the traditional patriarchal practices even in cyberspace. However, if the second assumption is true, Bangladesh's society might be on the brink of a mushrooming danger as misinterpreted religious knowledge not only would make women vulnerable but might also bring about social chaos and intensify gender inequality.

\section{Women's attire}

The concept of attire (poshak) could have been fit into the discussion of religion/religiosity. Nevertheless, I would like to separately emphasize how men policewomen in social media only targeting their costumes. Further, the dataset contains a high number of remarks where men expressed their deep concern regarding women's "slut-like" clothing that demands a comprehensive analysis. Two reasons may influence men's moral panic regarding women's attire: knowledge of/from popular Islam, and the notion of Bengali culture. According to popular Islamic sources, women are the "things" that must be "protected" and "secured" from the male gaze and aggression by either not going outside of the home or maintaining a veil. The idea of decency for women 
has partly emerged from this view.

"This is Bangladesh. Why a woman would go out of home wearing a t-shirt, even without urna covering her breast? Does Islam allow such dresses? Such women should be ashamed of!"

"T-shirts are not for women, and even though religious scripture is inscribed on it. Rather, you should obey religious instructions; properly wear hijab and decent dresses to roam around."

Interestingly, the t-shirt (Genji, what they call it) is considered as the symbol of vulgarity whereas burkha and hijab as Islamic dresses are recognized as the decent and proper attire for women. This view is rightly associated with the patriarchal (mis)interpretation of Islam and conveys an authoritative tone and imposition. The dress-related discussion, as it has been found, revolves around centering a few themes: porda (veiling), beporda (unveiled), oshalin (vulgar). This may seem like a soft form of digilantism.

However, the degree of digilantism increases while the verbal aggressiveness accompanies it. Men's statements signify how women are becoming "uncivilized", "vulgar" and "uncontrolled" according to the standard of their morality.

"Women can be highly lewd by crossing their limit. This (social campaigning) would not work if you go for room date and get fucked regularly."

"They (women) go out wearing vulgar dresses (t-shirt) so that men can touch their body."

Although Bangladesh society is now considered as a transitional one following rapid modernization, gender socialization remains highly rigid and traditional at the core of the society. Most of the women have certain roles to carry out in society those have mostly household works and no direct economic values (Mannan, 2011).

On the other hand, men control the social institutions and even women (Azad, 2004). This practice also lets the men have the authority to control and reconstruct culture according to their will. They, in this case, may not only reinvent patriarchic Islam but also patriarchic culture to subordinate women: it appears that this process continues in social media too. The concept of so-called Bengali culture thus only arranges the perfect ground for moral policing against women. 
"In Muslim-dominated society, if you wear short dresses (like t-shirts) and commute with men, they might stare at you as they are not used to it."

"These sisters (who campaigned) may be from higher society so wearing t-shirts and jeans is not a big deal for them. But they should have reminded me that Bangladesh girls should not be like this. People are sensitive in this issue because we want women to act like women: they should wear at least salwar kameez with veil [...] I think such dresses are very inappropriate in/with Bengali culture and this protest is vulgar. Vulgarity cannot be a language of protest."

Along with this view, something impressive has also been noticed in the dataset. According to several statements, an important reason why men do not want women to be more "expressive" in public is that it arouses men's sexuality. Instead of acknowledging so, men in social media ask women who gave them "the rights to provoke men wearing such horny dresses (t-shirt and jeans)" and why do not they understand "how hard it is for men to conceal this excitement". Even they suggest women "not to think men as impotent".

This view may suggest the expression and idea of men's virility and women's beauty, and men's aggression and women's subordination. The vilification of women's clothing here might be a mere veneer or excuse to perpetuate men's aggressiveness and toxic masculinity (Parent et al., 2019; Sculos, 2017) while ubiquitous in their use, have not been well integrated into psychological theory or practice. Most research addressing SM/SNs has examined frequency and modality of SM/SN use, rather than the valence of online interactions or potential mental health consequences of use. Further, SM/SN use has also not been well integrated with relevant paradigms from the psychology of men and masculinities paradigms. The present study contributes to both of these research need areas by testing the associations among SM/SN use, toxic masculinity, positive or negative SM/SN interactions, and depression among a sample of 402 men. Results of a structural equation modeling analysis indicated that $\mathrm{SM} / \mathrm{SN}$ use and toxic masculinity were associated with depression. Positive and negative $\mathrm{SM} / \mathrm{SN}$ interactions mediated the relationship between SM/SN use and depression indicators, and negative SM/SN interactions mediated the relationship between toxic masculinity and depression. Implications for future research directions and for working with men who use SM/SNs are discussed. (PsycINFO Database Record (c.

"Such dresses (t-shirt and jeans) would invite rapists. You Muslim girls must wear urna; girls from other nations may wish to wear whatever they 


\section{want."}

Referencing Islam and nationality, men try to attribute selected dress codes to women which might also be an expression of xenophobia. It is to note that except for a few Muslim countries, Christianity-dominated West is the foremost political rival of the Islamic world (Huntington, 2007). Thus, the fear of Westernization or Christianization, as we may observe across Muslim societies, has been rising so do the protest against it (Saikal, 2000, 2003). It should be mentioned here that before contemporary Islamization and/or Islamic protest, the clothing of women in Bangladesh society was more relaxed unlike now (Murshid, 2006; Ovi, 2018).

\section{Women's virtue}

The concept of character or virtue (choritro) has traditionally been associated with women (Mannan, 2011). To be more specific, Bangladesh has two types of women based on virtue, according to society: good women who have good character, and bad women who have bad character. Virtue or character in this sense is directly connected to the concept of morality and social norms. Such "morality" is also a patriarchal ideology. A woman becomes choritrohin (characterless) if she violates the rules created by society: most often, these attributions are closely related to women's bodies and sexuality. For example, deception and drinking might be immoral for men that are admissible, while having an extramarital affair is immoral for women that must be punished somehow. Taking these into account, I have found several terms and expressions in the dataset that in fact attempt to signify women's character. Of those, a wide range of slurs relating to women's character is used aggressively: oshlil (nasty), nongra (lewd), nosta (jezebel), and baje (spoiled) are a few.

"The country is now full of vulgarity because of these sluts. Even prostitution has to remain in the limit, but these harlots have already crossed the line."

It is worthy to mention that most of the men except very few question the moral character of women, not of men. Women's character is perceived as a susceptible thing that needs to be maintained and guarded heavily; once somehow if it is "tarnished", the woman may lose her dignity amid society. Interestingly, men in cyberspace perceive women wearing t-shirts lose their moral character since they should wear something Islamic as well as culture to preserve their so-called character. 
In social media, such forceful statements may also suggest the men's power over communication as well as women. The idea of the character depends on shalinota (decency), and for a woman, it is directly linked to her appearance, clothing, and behavior. To be decent, a woman should "hide their buk (breast) by urna (a piece of cloth)", and "pacha (buttock) and shorirer vaj (body shape) by burkha" from the male gaze; otherwise, her character might be perceived as stained.

"If you can hover around naked then why it is an issue if anyone molests you? When you wear an indecent dress, the bad men would grope you and the good ones would watch your breast, bra, and body shape. You women are corrupting us."

Although some men seemingly express their solidarity with women's emancipatory steps in social media, they postulate that women must follow the "social norms" to preserve their character. Surprisingly, the data suggests that it is the sole responsibility of a woman to protect her ijjot (honor) and sotitto (virginity) in any circumstance: even if a man tries to devour her, he would be exempted from this perpetration. The legalization of men's aggression on so-called choritrohin meye (characterless women) is remarkable ideation of the conversing men.

Women who tend to disrupt and/or challenge the male-made standard of characterization are addressed and described with various adjectives: behaya (shameless), kharap (wicked), potita (prostitute), magi (harlot), and baje (punk). According to some, men can have and do whatever they want to do to the "shameless", "wicked" and "characterless" "prostitutes".

"These are not women but cows (in sense of having breast and providing milk) who at first rape men's eye with their body and compel men to engage in raping afterward."

"If to be naked (what women do) is a protest, then, to rape (what men do) is a physical exercise."

These dialogues might be the index of men's aggressiveness and wish to exercise power, which is derived from real-life context to social media. In this case unlike the ideation of clothing, the cause of men's aggressiveness is women's character: it seems preserving women's virtue is a moral duty of men, and if women violate men's ordinance, they must be punished. Verbal aggressiveness similar to physical violence in this respect might be the expression of men's 
"sanctioned" authority and control over women (Wood, 2010).

\section{Key findings}

This research aimed to find out on what basis men conduct Islamic vigilantism and verbal aggressiveness against women in social media. To answer the query, I analyzed the relevant Facebook discourse data through the TA method. The three interlinked themes extracted from the dataset denote the main tenets of Islamic vigilantism and verbal aggressiveness against women in social media.

First, Muslim males as social media users think women should be strict followers of Islam. It seems their version of Islam is not much aligned with the core ideas of Islam. Rather, it is the patriarchic reproduction of Islamic ideologies. They commence the discourse of haram and halal to guide the daily lives of women: what they should wear and what they should not, how they should behave, and how they should not. These guidelines are more patriarchic than Islamic (Azad, 2004; Mannan, 2011). This limiting might be a way to control the actions of women in both virtual and physical space. They also give an analogy of Saudi Arabian women who are considered ideal. Conversely, they castigate feminist women, the Jewish, and the Hindus and blame them for corrupting Muslim women. Similarly, Second, the idea of ideal clothing poses great importance in Islamic vigilantism. Men try to set the dress codes for women based on "Islam". In this case, also, Islamic dress codes are misinterpreted and used in favor of men. While Islam does not impose strict discipline on women regarding clothing, men ban and impose dress codes referring to Islam. It supports the claims of Barlas (2019) and Saadawi (2015). Third, women's character is attacked repeatedly by the Muslim male netizens who use to call women behaya (shameless) and choritrohin (characterless). According to them, most women are becoming characterless and uncontrolled due to following the un-Islamic traditions. As a result, women endure online body shaming by male netizens. Such acts of digilantism are serious instances of online misogyny that Jane (2014b, 2014a, 2016, 2017a, 2017b)the mainstream media has identified on-line vitriol as a worsening problem which is silencing women in public discourse, and is having a deleterious effect on the civility of the public cybersphere. This article examines the disconnect between representations of "e-bile" in media texts, and representations of e-bile in academic literature. An exhaustive review of thirty years of academic work on "flaming" shows that many theorists have routinely trivialized the experiences of flame targets, 
while downplaying, defending, and/or celebrating the discourse circulated by flame producers. Much contemporary scholarship, meanwhile, ignores e-bile completely. My argument is that this constitutes a form of chauvinism (in that it disregards women's experiences in on-line environments talks about. But what could the reasons for such Islamic vigilantism in social media?

We can presume a few possible drivers behind this propensity: an important one is related to Islamic revivalism is Bangladesh (Islam \& Islam, 2018). Due to this revival, the social environment is becoming rigid and controlled and influenced by the religious authorities. Islam in this context is more than a religion. While a version of Islam takes the route to politics, another version makes a successful marriage between social norms and Islamic codes of conduct, i.e., sharia, to some extent, possible. Thus, Islam as an ideology (Barkat, 2018) is simultaneously pushing both Islamic fundamentalism/militancy and socioreligious practices of Islam forward. A shadow of this social trend is perhaps present in social media as well (Al-Zaman, 2019). Also, as a tool of resistance, Islam has a proven value meanwhile (Waardenburg, 1985). As pan-Islamism and the anti-Western sentiment is conceivably rising across Bangladesh as well as other Muslim countries, it becomes easier for Muslim men, supported by patriarchy (Chowdhury, 2009; Schuler et al., 1996; Sultana, 2010), to designate any behavior, culture, trend, and products of women as "foreign" to castigate them. (In Bangladesh, people denote "Western" with the word "foreign"). Following the idea that social media is a reflection of society (Bowman, 2013; Hodkinson, 2010), I would like to surmise that men's patriarchic domination has been accommodated into cyberspace as well which is now pushing women to the margin.

We have already seen that majority of the conversing men engage in common topics, have commonly shared values, and feel an association between them thanks to these common issues. Facebook as a crucial SNS makes the interaction between these men possible so that they can discuss their commonality and share information that helps them to govern the discourse as well as women in the virtual platform. This not only provides meaning to their relations but also determines the relations of domination. While shared Islamic ideology binds the men together in social media, as per the findings, a common standard of morality arises. This emerged a sense of common moral standard that might be the base of Islamic digilantism against women. Men expect women to be more obedient (religious), modest (veiled), and pure (virtuous) according to their reinvented sense of morality since they perceive such behaviors as either most 
typical or normative (Houser, 2005). While the campaigning women violate their expectations, they get furious and start displaying verbal aggressiveness as we have seen in their dialogues.

However, some of the male participants in the discourse have indeed shown a moderate degree of assertiveness and responsiveness at the same time, which means their dialogues were more submissive and constructive than the majorities'. What most of the men have displayed is their verbal aggressiveness including attacks on the women's character, physical appearance, and background (Littlejohn \& Foss, 2009). They have mocked, teased, and objurgated as well. It could reward women with numerous negative impacts, such as abstaining from participating in social media discourses, feeling of insecurity even in mediated communication, depression, feeling of rightlessness and disempowerment, and so on.

\section{CONCLUSION}

To conclude, this research has limitations from three aspects. First, although the study is built on TA within the qualitative paradigm, it is often undervalued as a full-fledged research method as stated earlier. Therefore, it could be problematic for this newly-developed method to analyze social media data. Second, the findings of the research are not space and time-neutral; therefore, they might not be generalized for other Muslim countries except Bangladesh due to the sociocultural and sociopolitical differences. Third, cyberspace research in Bangladesh is yet to be formally recognized in academia, thus it is still in its infancy. Thereby, this paper as a pioneer in its field may have weaknesses in arranging, explicating, and knitting the whole parts together. Apart from these shortcomings, the present paper would lead to further researches in this area.

\section{REFERENCES}

Ahmad, M. (2005, August 31). "Veiled" moral policing in J\&K. Rediff. https:// www.rediff.com/news/2005/aug/30veil.htm

Aichner, T., \& Jacob, F. (2015). Measuring the degree of corporate social media use. International Journal of Market Research, 57(2), 257-276. https://doi. org/10.2501/IJMR-2015-018

Al-Saggaf, Y. (2006). The online public sphere in the Arab world: The war in Iraq on the Al Arabiya website. Journal of Computer-Mediated Communication, 
12(1), 311-334. https://doi.org/10.1111/j.1083-6101.2006.00327.x

Al-Zaman, Md. S. (2019). Digital disinformation and communalism in Bangladesh. China Media Research, 15(2), 68-76.

Anderson, C. M., \& Martin, M. M. (1999). The relationship of argumentativeness and verbal aggressiveness to cohesion, consensus, and satisfaction in small groups. Communication Reports, 12(1), 21-31. https://doi. org/10.1080/08934219909367705

Anderson, C. M., \& Rancer, A. S. (2007). The relationship between argumentativeness, verbal aggressiveness, and communication satisfaction in incarcerated male youth. The Prison Journal, 87(3), 328-343. https:// doi.org/10.1177/0032885507304433

Ayres, L. (2008). Thematic coding and analysis. In The SAGE Encyclopedia of Qualitative Research Methods (pp. 868-868). SAGE Publications, Inc. https://doi.org/10.4135/9781412963909

Azad, H. (2004). Women (3rd ed.). Agamee Prakashani.

Baldauf, H., Develotte, C., \& Ollagnier-Beldame, M. (2017). The effects of social media on the dynamics of identity: Discourse, interaction and digital traces. Alsic. Apprentissage Des Langues et Systèmes d'Information et de Communication, Vol. 20, n 1. http://journals.openedition.org/alsic/3004

Banerjee, T. (2019, August 19). Kolkata: Moral policing victim records statement before women's commission. The Times of India. https://timesofindia. indiatimes.com/city/kolkata/kolkata-moral-policing-victim-recordsstatement-before-womens-commission/articleshow/70610921.cms

Barkat, A. (2018). Fundamentalism in Bangladesh: External and internal dimensions of the political economy of militancy. Muktobuddhi Publisher.

Barlas, A. (2019). Believing women in Islam: Unreading patriarchal interpretations of the Qur'an. University of Texas Press.

BBC News. (2019, April 7). Story of "Ga gheshe daraben na." BBC News Bangla. https://www.bbc.com/bengali/news-47843402

Bekiari, A., \& Pachi, V. (2017). Insights into bullying and verbal aggressiveness through social network analysis. Journal of Computer and Communications, 5(9), 79-101. https://doi.org/10.4236/jcc.2017.59006

Bordens, K. S., \& Abbott, B. B. (2017). Research design and methods: A process approach (10th ed.). McGraw-Hill Education.

Bowman, N. D. (2013). Media as a reflection of society. In Encyclopedia of 
Media Violence (pp. 234-235). SAGE Publications, Inc. https://doi. org/10.4135/9781452299655

Boyatzis, R. E. (1998). Transforming qualitative information: Thematic analysis and code development. Sage Publications, Inc.

Braun, V. (2013). Successful qualitative research: A practical guide for beginners. Sage Publications.

Braun, V., \& Clarke, V. (2006). Using thematic analysis in psychology. Qualitative Research in Psychology, 3(2), 77-101. https://doi. org/10.1191/1478088706qp063oa

Brown, W. R. (1978). Ideology as communication process. Quarterly Journal of Speech, 64(2), 123-140. https://doi.org/10.1080/00335637809383420

BTRC. (2019). Internet subscribers in Bangladesh [Statistics]. Government of the people's Republic of Bangladesh. http://www.btrc.gov.bd/content/ internet-subscribers-bangladesh-june-2019

Carey, J. W. (2008). Communication as culture, revised edition: Essays on Media and Society. Routledge.

Chaity, A. J. (2017, November 8). Is Bangladesh really closing gender gap? Dhaka Tribune. https://www.dhakatribune.com/bangladesh/2017/11/08/ bangladesh-really-closing-gender-gap

Chaity, A. J. (2018, July 11). Women empowerment: Bangladesh sets example for the world. Dhaka Tribune. https://www.dhakatribune.com/opinion/ special/2018/07/12/women-empowerment-bangladesh-sets-example-forthe-world

Chang, L. Y. C., \& Poon, R. (2017). Internet vigilantism: Attitudes and experiences of university students toward cyber crowdsourcing in Hong Kong. International Journal of Offender Therapy and Comparative Criminology, 61(16), 1912-1932. https://doi.org/10.1177/0306624X16639037

Chowdhury, F. D. (2009). Theorising patriarchy: The Bangladesh context. Asian Journal of Social Science, 37(4), 599-622. https://doi. org/10.1163/156853109X460200

Cops didn't trip, lovers were target-Operation Majnu: Crackdown on couples, not eve-teasers. (2005, December 21). The Telegraph. https://www. telegraphindia.com/india/cops-didn-t-trip-lovers-were-target-operationmajnu-crackdown-on-couples-not-eve-teasers/cid/831756

Dahlberg, L. (2001). Computer-mediated communication and the public 
sphere: A critical analysis. Journal of Computer-Mediated Communication, 7(1). https://doi.org/10.1111/j.1083-6101.2001.tb00137.x

Devine, J., \& White, S. C. (2013). Religion, politics and the everyday moral order in Bangladesh. Journal of Contemporary Asia, 43(1), 127-147. https://doi. org/10.1080/00472336.2012.735544

Douki, S., Nacef, F., Belhadj, A., Bouasker, A., \& Ghachem, R. (2003). Violence against women in Arab and Islamic countries. Archives of Women's Mental Health, 6(3), 165-171. https://doi.org/10.1007/s00737-003-0170-x

Esfandiari, H. (1997). Reconstructed lives: Women and Iran's Islamic Revolution. Woodrow Wilson Center Press.

Foucault, B., \& Melican, J. (2007). The digital and the divine: Taking a ritual view of communication and ICT interaction. In N. Aykin (Ed.), Usability and Internationalization. HCI and Culture (pp. 74-82). Springer Berlin Heidelberg.

Frey, B. B. (2018). Johari Window. In The SAGE Encyclopedia of Educational Research, Measurement, and Evaluation. SAGE Publications, Inc. https:// doi.org/10.4135/9781506326139.n363

Gaffney, P. D. (1992). Popular Islam. The Annals of the American Academy of Political and Social Science, 524(1), 38-51. https://doi. org/10.1177/0002716292524001004

Ging, D., \& Siapera, E. (2018). Special issue on online misogyny. Feminist Media Studies, 18(4), 515-524. https://doi.org/10.1080/14680777.2018.144734 5

Hasan, M. M. (2012). Feminism as Islamophobia: A review of misogyny charges against Islam. Intellectual Discourse, 20(1). https://journals.iium.edu.my/ intdiscourse/index.php/islam/article/view/192

Hashmi, T. (2000). Women and Islam in Bangladesh: Beyond subjection and tyranny. Palgrave Macmillan. https://www.palgrave.com/gp/ book/9780333749593

Herold, D. K. (2008). Development of a civic society online? : Internet vigilantism and state control in Chinese cyberspace. http://ira.lib.polyu.edu.hk/ handle/10397/4434

Hodkinson, P. (2010). Media, culture and society: An introduction. Sage Publications.

Holliday, A. (2010). Intercultural communication $\mathcal{E}$ ideology: SAGE Publications. SAGE. 
Informasi, Vol. 51. No. 1. (2021), 65-92

Houser, M. L. (2005). Are we violating their expectations? Instructor communication expectations of traditional and nontraditional students. Communication Quarterly, 53(2), 213-228. https://doi. org/10.1080/01463370500090332

Huntington, S. P. (2007). The clash of civilizations and the remaking of world order. Simon and Schuster.

India's moral police declare war on decadence. (2006, November 11). The Age. https://www.theage.com.au/world/indias-moral-police-declare-war-ondecadence-20061111-ge3jot.html

Infante, D. A. (1987). Aggressiveness. In McCroskey, J. C. \& Daly, J. A. (Eds.), Personality and interpersonal communication (pp. 157-192). SAGE Publications.

Infante, D. A., \& Rancer, A. S. (1996). Argumentativeness and verbal aggressiveness: A review of recent theory and research. Annals of the International Communication Association, 19(1), 319-352. https://doi.org /10.1080/23808985.1996.11678934

Infante, D. A., Riddle, B. L., Horvath, C. L., \& Tumlin, S. A. (1992). Verbal aggressiveness: Messages and reasons. Communication Quarterly, 40(2), 116-126. https://doi.org/10.1080/01463379209369827

Infante, D. A., \& Wigley, C. J. (1986). Verbal aggressiveness: An interpersonal model and measure. Communication Monographs, 53(1), 61-69. https:// doi.org/10.1080/03637758609376126

Islam, Md. N., \& Islam, Md. S. (2018). Politics and Islamic revivalism in Bangladesh: The role of state and non-state actors. Politics, Religion and Ideology. https://doi.org/10.1080/21567689.2018.1493382

Jane, E. A. (2014a). 'Back to the kitchen, cunt': Speaking the unspeakable about online misogyny. Continuum, 28(4), 558-570. https://doi.org/10.1080/ 10304312.2014.924479

Jane, E. A. (2014b). "You're a Ugly, Whorish, Slut." Feminist Media Studies, 14(4), 531-546. https://doi.org/10.1080/14680777.2012.741073

Jane, E. A. (2016). Online misogyny and feminist digilantism. Continuum, 30(3), 284-297. https://doi.org/10.1080/10304312.2016.1166560

Jane, E. A. (2017a). Misogyny online: A short (and Brutish) history. Sage Publications.

Jane, E. A. (2017b). Feminist digilante responses to a slut-shaming on Facebook. Social Media + Society, 3(2), 2056305117705996. https://doi. 
org/10.1177/2056305117705996

Johnston, L. (1996). What is vigilantism? The British Journal of Criminology, 36(2), 220-236. https://doi.org/10.1093/oxfordjournals.bjc.a014083

Klang, M. (2015). On the internet nobody can see your cape: The ethics of online vigilantism. AoIR Selected Papers of Internet Research, 5. https:// firstmonday.org/ojs/index.php/spir/article/view/8766

Kosseff, J. (2016). The hazards of cyber-vigilantism. Computer Law $\mathcal{E}$ Security Review, 32(4), 642-649. https://doi.org/10.1016/j.clsr.2016.05.008

Lewis, D. (2011). Bangladesh: Politics, economy and civil society. Cambridge University Press.

Littlejohn, S. W., \& Foss, K. A. (2009). Encyclopedia of communication theory. SAGE Publications.

Mannan, P. Md. A. (2011). Grameen Nari (Rural Women). Abosar Prokashoni.

Manne, K. (2018). Down girl: The logic of misogyny. Oxford University Press.

Marlow, I. (2019, February 20). Cow vigilantes in India killed at least 44 People, report finds. Bloomberg. https://www.bloomberg.com/news/ articles/2019-02-20/cow-vigilantes-in-india-killed-at-least-44-peoplereport-finds

Martin, M. M., \& Anderson, C. M. (2007). Argumentativeness and verbal aggressiveness. Journal of Social Behavior and Personality, 11(3), 547-554.

Moloney, M. E., \& Love, T. P. (2018). Assessing online misogyny: Perspectives from sociology and feminist media studies. Sociology Compass, 12(5), e12577. https://doi.org/10.1111/soc4.12577

Momin, S. M. (2019, April 12). Making public transport safe for women. The Independent. http://www.theindependentbd.com/printversion/ details/195442

Monitoring, B. B. C. (2016, April 22). Who are Islamic "morality police"? BBC News. https://www.bbc.com/news/world-middle-east-36101150

Moral police runs riot in capital. (2010, February 15). The Telegraph. https:// www.telegraphindia.com/states/jharkhand/moral-police-runs-riot-incapital/cid/548965

Mudhai, O., Tettey, W., \& Banda, F. (2009). African media and the digital public sphere. Springer.

Mumby, D. K. (1989). Ideology \& the social construction of meaning: A 
communication perspective. Communication Quarterly, 37(4), 291-304. https://doi.org/10.1080/01463378909385551

Murshid, G. (2006). Bengali culture of thousand years. Oboshor Publication.

Nandi, J. (2013, February 5). Art attack: Moral police threaten nudes exhibition. The Times of India. https://timesofindia.indiatimes.com/city/delhi/Artattack-Moral-police-threaten-nudes-exhibition/articleshow/18342297. $\mathrm{cms}$

Nanjappa, V. (2009, January 26). "Moral police" attack Mangalore pub. Rediff. https://www.rediff.com/news/2009/jan/26sri-ram-sena-attacksmangalore-pub.htm

Nhan, J., Huey, L., \& Broll, R. (2017). Digilantism: An analysis of crowdsourcing and the Boston marathon bombings. The British Journal of Criminology, 57(2), 341-361. https://doi.org/10.1093/bjc/azv118

Ovi, S. (2018, May 1). A brief history of native costume. Weekly Mohinilok, 26(1), 20-26.

Ozdalga, E. (2013). The veiling issue, official secularism and popular Islam in modern Turkey. Routledge.

Papacharissi, Z. (2002). The virtual sphere: The internet as a public sphere. New Media ES Society, 4(1), 9-27. https://doi.org/10.1177/14614440222226244

Parent, M. C., Gobble, T. D., \& Rochlen, A. (2019). Social media behavior, toxic masculinity, and depression. Psychology of Men $\mathfrak{E}$ Masculinities, 20(3), 277-287. https://doi.org/10.1037/men0000156

Plant, S. (2000). On the matrix: Cyberfeminist simulations. In Kennedy, B. M. \& Bell, D. (Eds.), The Cybercultures Reader (pp. 325-336). Routledge.

Poor, N. (2005). Mechanisms of an online public sphere: The website slashdot. Journal of Computer-Mediated Communication, 10(2). https://doi. org/10.1111/j.1083-6101.2005.tb00241.x

Prins, C. (2010). The online dimension of recognised victims' rights. Computer Law $\mathcal{E}$ Security Review, 26(2), 219-221. https://doi.org/10.1016/j. clsr.2010.01.005

PTI. (2017, December 11). Only 29\% female Internet users in India: UNICEF report. The Economic Times. https://economictimes.indiatimes.com/ tech/internet/only-29-female-internet-users-in-india-unicef-report/ articleshow/62027590.cms

Ramazani, N. (1993). Women in Iran: The revolutionary ebb and flow. Middle 
East Journal, 47(3), 409-428. JSTOR.

Riaz, A. (2016). Bangladesh: A political history since independence (Sew edition). I.B. Tauris \& Co Ltd.

Riaz, A. (2017). Lived Islam and Islamism in Bangladesh. Prothoma Prokashan.

Rieder, B. (2013). Studying facebook via data extraction: The netvizz application. Proceedings of the 5th Annual ACM Web Science Conference, 346-355. https://doi.org/10.1145/2464464.2464475

Rosenbaum, H. J., \& Sederberg, P. C. (1974). Vigilantism: An analysis of establishment wiolence. Comparative Politics, 6(4), 541-570. JSTOR. https://doi.org/10.2307/421337

Roulston, K. (2001). Data analysis and 'theorizing as ideology.' Qualitative Research, 1(3), 279-302. https://doi.org/10.1177/146879410100100302

Ruiz, C., Domingo, D., Micó, J. L., Díaz-Noci, J., Meso, K., \& Masip, P. (2011). Public sphere 2.0? The democratic qualities of citizen debates in online newspapers. The International Journal of Press/Politics, 16(4), 463-487. https://doi.org/10.1177/1940161211415849

Saadawi, N. E. (2015). The hidden face of eve: Women in the Arab world. Zed Books Ltd.

Saikal, A. (2000). 'Islam and the West'? In G. Fry \& J. O'Hagan (Eds.), Contending images of world politics (pp. 164-177). Macmillan Education UK. https:// doi.org/10.1007/978-0-333-98553-3_12

Saikal, A. (2003). Islam and the West: Conflict or cooperation? Palgrave Macmillan.

Samant, A. S. (2009, February 7). (Im)moral policing. Zee News. https:// zeenews.india.com/exclusive/immoral-policing_2223.html

Schäfer, M. S. (2016). Digital public sphere. In The International Encyclopedia of Political Communication (pp. 1-7). American Cancer Society. https://doi. org/10.1002/9781118541555.wbiepc087

Schendel, W. V. (2009). A history of Bangladesh. Cambridge University Press.

Schilder, K. (1990). Popular Islam in Tunisia: A regional cults analysis. 44. https:// www.africabib.org/rec.php?RID=079961630

Schuler, S. R., Hashemi, S. M., Riley, A. P., \& Akhter, S. (1996). Credit programs, patriarchy and men's violence against women in rural Bangladesh. Social Science $\mathcal{E}$ Medicine, 43(12), 1729-1742. https://doi.org/10.1016/S02779536(96)00068-8 
Schwarz, K. C., \& Richey, L.A. (2019). Humanitarian humor, digilantism, and the dilemmas of representing volunteer tourism on social media. New Media $\mathcal{E}$ Society, 21(9), 1928-1946. https://doi.org/10.1177/1461444819834509

Sculos, B. (2017). Who's Afraid of 'Toxic Masculinity'? Class, Race and Corporate Power, 5(3). https://doi.org/10.25148/CRCP.5.3.006517

Smallridge, J., Philip, W., \& Justin, N. C. (2016). Understanding cybervigilantism: A conceptual framework. Journal of Theoretical $\mathcal{E}$ Philosophical Criminology, 8(1), 57-70.

Social Media Stats Bangladesh. (2019, May). Stat Counter. http://gs.statcounter. com/social-media-stats/all/bangladesh

Social Media Stats Bangladesh. (2019, May). Stat Counter. http://gs.statcounter. com/social-media-stats/all/bangladesh

Srivastava, K., Chaudhury, S., Bhat, P. S., \& Sahu, S. (2017). Misogyny, feminism, and sexual harassment. Industrial Psychiatry Journal, 26(2), 111113. https://doi.org/10.4103/ipj.ipj_32_18

Sultana, A. (2010). Patriarchy and women's subordination: A theoretical analysis. Arts Faculty Journal, 4(1), 1-18. https://doi.org/10.3329/afj. $\mathrm{v} 4 \mathrm{i} 0.12929$

Terry, G., Hayfield, N., Clarke, V., \& Braun, V. (2017). Thematic analysis. In Willig, C. \& Rogers, W. S. (Eds.), The SAGE handbook of qualitative research in psychology (pp. 17-36). Sage Publication. https://doi. org/10.4135/9781526405555.n2

Topel, M. F. (2012). Jewish orthodoxy and its discontents: Religious dissidence in contemporary Israel. Rowman \& Littlefield.

Trottier, D. (2017). Digital vigilantism as weaponisation of visibility. Philosophy $\mathcal{E}$ Technology, 30(1), 55-72. https://doi.org/10.1007/s13347-016-0216-4

Uddin, S. M. (2006). Constructing Bangladesh: Religion, ethnicity, and language in an Islamic nation. The University of North Carolina Press.

Vaismoradi, M., Turunen, H., \& Bondas, T. (2013). Content analysis and thematic analysis: Implications for conducting a qualitative descriptive study. Nursing $\mathcal{E}$ Health Sciences, 15(3), 398-405. https://doi.org/10.1111/ nhs. 12048

Waardenburg, J. (1985). Islam as a vehicle of protest. In E. Gellner (Ed.), Islamic dilemmas: Reformers, nationalists, industrialization: The Southern Shore of the Mediterranean (Vol. 25). Mouton. 
Wajcman, J. (2010). Feminist theories of technology. Cambridge Journal of Economics, 34(1), 143-152. https://doi.org/10.1093/cje/ben057

Why India needs women to work. (2018, July 5). The Economist. https://www. economist.com/leaders/2018/07/05/why-india-needs-women-to-work

Wilk, A. van der. (2018). Cyber violence and hate speech online against women (Research PE 604.979). European Union. https://publications.europa. eu/en/publication-detail/-/publication/1ccedce6-c5ed-11e8-942401aa75ed71a1/language-en/format-PDF/source-77711773

Wood, J. T. (2010). Gendered lives: Communication, gender and culture. Cengage Learning. 
Informasi, Vol. 51. No. 1. (2021), 65-92 